\title{
Women On Marriage Values And Divorce Mechanisms In The Butonese Of The Southeast Sulawesi (Edmund Husserl Phenomenological Study)
}

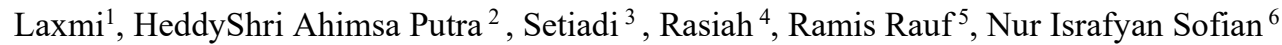 \\ \{laxmi@uho.ac.id ${ }^{1}$, ahimsaputra@gmail.com ${ }^{2}$, setiadi@gmail.co.id ${ }^{3}$, rasiah@yahoo.co.id ${ }^{4}$, \\ ramis.rauf@gmail.co.id ${ }^{5}$, nur.sofian@gmail.com $\left.{ }^{6}\right\}$ \\ ${ }^{123456}$ Faculty of Humanities,Universitas Halu Oleo Kendari, Sulawesi Tenggara, Indonesia
}

\begin{abstract}
Marriage and divorce are two different sides of domestic life. They have seized the attention that not only happened in urban communities, but also rural areas. This study investigated women as divorce planners in Baubau and the strengthening value of marriage for Butonese women through the Posuo tradition, as well as the mechanism of divorce in the context of ethnic groups. This study approached the data through Edmund Huserl's phenomenology theory. It is emphasizing on the ones' consciousness that lead to the life world. "Consciousness" is used here as a model for understanding marriage which has implications for the divorce of Buton women. The result of this study showed that the increasing cases of divorce in Buton that involved women as the divorce planners related to women's awareness and ability to negotiate with themselves and household problems. It is also showed that Butonese has a medium to strengthen the value of marriage by giving women education about married life before they got to it. In the mechanisme of divorce, woman perceived an easy way to get through when they become the plaintiff.
\end{abstract}

Keywords- Divorce, mechanism, marriage values, phenomenology.

\section{Introduction}

Divorce is not a new phenomenon in society but today become very popular in social media, both online or offline.The media pointed not only the variety of cases that lead to the divorce matters, but also the divorce planners. It is found that women as divorce planners is increased in the present decades not only occured in urban community but also rural area. Supreme Court's website that released on April 2019 reported there were 419.268 divorced couples in 2018 in Indonesia. It is then specified that women who filed for divorce are higher than those men. From 419. 268 cases, 307.778 cases were lawsuited by women and 111.490 from men. It is a mirror for all region in Indonesia.

Divorce is a seriously traumatic experience for sure. Experiencing divorce is strictly traumatic for anybody [1]. In Ghana, from a research by Nyamekye and friends found that divorce has affected social life in the country [2]. The focus of this study covers the stage 
toward divorce, namely isolation, cancellation and treason. In the other hand, Hartlein and friends in their reserach focus on to the family member who gives supports and sympathy by sharing with friends and family to those who were in a process towards divorce [3]. Ahimsa Putra sees this phenomenon as the new paradigm which shows the evolution of social science [4]. From functionalism perspective, Davis and Tuttle elaborated the specific of the religion institution's role in marriage dissolution [5]. Jhonson then illustrated that divorce, in family relationship perspective, has the access line to the family relationship structure due to the parenting relationship [6]. Homayuni and Hashemi used the interpretative perspective in studying about complexity of divorce process cases in Iran [7]. Kandri and friends in their research viewed that divorce impact has systemic influencing impact to every family member [8]. Milliar and Crosse explain about domestic violence experienced by woman in divorce and separation process [9]. From the talks it can be seen that, divorce as a traumatic case has been taking a huge attention in academic various perspective.

The present study lifted out Baubau as one urban area in the Southeast Sulawesi that also has problematic case about divorce. The Supreme Court of Baubau reported that the number of divorce in this small urban dominated by women as lawsuit who want to get divorce. The phenomenon of divorce rates is not only occured in the lower classes peole, but also in highe class ones. It is evenly distributed in almost all class of societies [10].

However, Butonese people as an ethnic community also have its medium to put women in marriage values. It is called posuo. Posuo is one of them - that is a ritual for Butonese women before entering marriage life. Agus Sana'a, a former son of the preacher of the Buton Keraton mosque explained that posuo is a means toeducate and train girls beforelive the ark of home lifestairs [11]. It is believed haveethical, moral, spiritual values and individual messages. These valuesreserved for Buton girls related to their status as children, wife, mother, and his position aspart of the community that has beenentering adulthood. In short, Posuois an initiation process as the part of rites of passage for Buton girl to become a mature woman before entering marriage life. Experiencing posuo for Butonese women is building their consciousness and meaning for their existence as a woman. Husserl, in line with it, said that this consciousness tends to be intentional. Intentionality refers to the intrinsic structure for human consciousness.

Looking at the background of Butonese women and their bases in raising themselves as a mature women through posuo, it can be said that they have almost no room for misunderstanding to cause divorce in the household. In fact, it is inversely proportional. Women are said to be precisely as the most plaintiffs in divorce cases in the city of Baubau in the current period. Thus, the presents study aims at elaborating divorce case in Baubau and women in posue tradition, as well as the mechanism of divorce experienced by women. It is elaborated based on constitution concept in phenomenology approach. Constitution is a process when phenomenon is seen on one's consciousness in the constitution. There is a construction process of human consciousness. It can be seen that one could a constitution and realize the possibility. Constitution is something seen from subject point of view to interpret the experienced world and universe. In this aspect, Butonese women interpret about divorce. The main point is on how divorce becomes life experiences felt by woman in Baubau. This study employed both describtive qualitative and quantitativeintrepretive analysis by approaching the phenomenology perspective. 


\section{Result And Discussion}

\subsection{The Increasing Rates of Women Lawsuit on Divorcein Baubau}

Data from Religious Court Baubau released on April 2019, performed that the divorce rates in Baubau city is higher from time to time. It is detailed in 2016, it is reported 261 cases of divorce plans registered in Religious Court Baubau, 326 cases in 2017, and 344 in 2018. It is detailed can be showed in the following table.

Table 1 The Divorce Rates in Baubau in Three Years Back

\begin{tabular}{cccccc}
\hline Year & Aged 20 & Aged 30 & Aged 40 & Aged 50 & Divorce case in total \\
\hline 2016 & 93 & 103 & 54 & 11 & 261 \\
2017 & 113 & 134 & 48 & 13 & 326 \\
2018 & 121 & 150 & 61 & 12 & 344 \\
\hline
\end{tabular}

From the table, it can be seen that the divorce cases evenly distributed to ages between 20 up to 50 years old people. It is also reported that the from the data, the women lawsuit on divorce is higher than those men. It is described that, $60 \%$, fromthe divorce cases, are from women almost all in the given eras. It is also come from all segment of social class and age.

Table 2 Divorce Rates Lawsuited by Women

\begin{tabular}{ccc}
\hline Year & Divorce cases total & Divorce lawsuited by women \\
\hline 2016 & 261 & 158 \\
2017 & 326 & 195 \\
2018 & 344 & 200 \\
\hline
\end{tabular}

The table demonstrated the rates of of divorces that lawsuited by women more or less $60 \%$ from the total cases. In 2016, the cases reported that from 261 cases, 158 cases are from women, in 2017, 326 cases, 195 were reported lawsuited by women, and in 2018, 200 from 344 cases reported came from women.

Many factors that triggering the high divorce number [10]. She listed increasing wife's education, ages, increasing women's awareness of their rights as a result of increasing gender insight, differences in religion and beliefs, and economic independence of a wife as a result of opened women's / wife's access to economic resources. Mr. H. Mansur K as the Judge in Supreme Cout of Baubau revealed that the factors that cause the high divorce numbers is mostly due to quarrels and disputes. The other is because of drunkenness, economic problems, gambling, and long disatance relatisonship.

\subsection{The Experience of Butonese Woman in Divorce Mechanism}

Harahap said that "incompatibility" terminologybetween a husband and a wife included in the compilation of Islamic Laws needs to be well reviewed [12]. According to him, the word (in social point of view) implies not on the level of humanity but outside of humanity. This word can be interpreted as an unmatched between husband and wife's relationship. This understanding is far from the character, nature and emotions of husband and wife that should be where they must have characters that attract each other. One of the consequences according to Harahapis when there is a conflict, the wife, regardless the risk, is willing to divorce her husband. Some of Butonese women told about their experiences in filing for divorce at the Baubau Religious Court that the divorce proceedings were relatively faster than previously 
thought. Persuasively at the divorce case hearing, the judge tried to reconcile the plaintiff and the defendant in the trial. That is why, both parties must present personally without being represented by anybody. This has actually been contained in law No. 7/1989 in article 82 concerning to the religious court.

Based on the data within mediation agenda in the divorce case from 2017 up to 2019, it is known that the level of mediation in the Religious Courtof Baubau showed that there were status of successful mediation, unsuccessful mediation, failure, and peace. To carry out mediation, mediators have freedom to create number of opportunities that help husband and wife to find an agreement that can end their dispute. Mediators should make every effort to support husband and wife in considering possibilities could happen to overcome the conflict.

\subsection{Marriage: Interpretation of Butonese women in Posuo Ritual}

In Wolio language Dictionary the word posuo comes from a combination of two words in Wolio langauge, Po as a prefix of to make the verb, and Suo means back room [13]. So, literally posuo can be interpreted as confinement activity in the back room of the house. Posuo, then, is identified as a process of confinement in back room of the house for women in a certain amount of time, and they don't allowed to connect with the world in the outside [14]. This has become a tradition of Buton society since several centuries then, in the era of the Buton Sultanate. The people assumed that women have beauty that can invite criminal vulnerability. Through posue, the men can see girls only at certain times such as family events [11].

Regardless of the meaning of confinement activity, Posue actually has a tremendous values for women. Posuo teaches women mainly in both aspect, tradition and how to be a wife in a household [15]. Engku then added that posuo is a traditional ceremony held by every parents as the initiation process for a litle girl to become a mature woman as the psychologically and mentally preparation to be a mature wife. Knowledge or teachings that obtained during posue expectedto become a lesson for womenbefore entering the household ark [16]. The initiation is neeed for human to enter a transition moment in life. It is a life cycle of human being [17]. In the other words, posue from Butonese cultural point of view is regarded as the guidelines in women in household life. Some of messages from Butoness elders can be seen in Onina Manga MancuanaMangenge. Alamsyah elaborated the messages of Butonese elder to the people, one of them is women [18]. It contains guidelines for woman should do before entering the marriage life in a household. The main function of utterances from the elders is the indication of formula for character building that consciously accepted by the young generations.

Looking at the case of divorce cased lawsuited by women in Buton regency, it is indicated that posue and divorce matter is somewhat different. Women keep doing posuo, but inequality in hosehold is something different that should be fighted. Posuo also is getting more attention in the present decade to solve the problem of divorce in Baubau.

\section{Conclusion}

This study may conclude that women in mariage values in Butonese culture are protected and inherited through posue tradition. Posuo has to be a medium to construct the good character of Butonese women. However, this does not have a close correlation with divorce matter. The number of divorces in Baubau is increased and caused by the alot of cases. One of them is inequality. Women seemed have been internalized gender mainstream, so, they do not let the unfair cases occured to them. They also have been educated and equipped themselves with 
sufficient welfare. In the mechanisme of divorce, when woman becomes the plaintiff, the defendant (husband) never comes to the judge even if he is always called for several times in a proper way. Before the judge makes decision, the judges try to mediate husband and wife to avoid conflict and even divorce. However, this negotiation is always getting failed and it is only 2 - 4 succeed cases during 2017 - 2019. The experience in filed the divorce book has the mechanism to submit. The mechanism is very easy and in a good procedure to run and also done by Religious Court. It can be seen that within the constitution, there is a construction process of human consciousness, especially women, in marriage and divorce.

\section{Reference}

[1] G. M. Lloyd, J. L. Sailor, and W. Carney, "A Phenomenological Study of Postdivorce Adjustment in Midlife," J. Divorce Remarriage, vol. 55, no. 6, 2014.

[2] K. O. Asante, J. Osafo, and G. K. Nyamekye, "An Exploratory Study of Factors Contributing to Divorce Among Maried Couples in Acra, Ghana: A Qualitative Approach," J. Divorce Remarriage, vol. 55, no. 1, 2014.

[3] B. Fladmo and K. M. Hertlein, "The Effect of Negative and Positive Childhood Divorce Experiences on Professional Performers," J. Divorce Remarriage, vol. 58, no. 8, pp. 584-598, 2017.

[4] H. S. Ahimsa-Putra, "Fenomenologi Agama: Pendekatan Fenomenologi Untuk Memahami Agama," Walisongo J. Penelit. Sos. Keagamaan, vol. 20, no. 2, 2012.

[5] J. D. Tuttle and S. N. Davis, "Religion, Infidelity, and Divorce: Reexamining the Effect of Religious Behavior on Divorce Among Long-Married Couples," J. Divorce Remarriage, vol. 56, no. 5, 2015.

[6] C. L. Johnson, "In-Law Relationships in the American Kinship System: The Impact of Divorce and Remarriage," Am. Antropol. Assoc., vol. 16, no. 1, pp. 87-99, 1989.

[7] L. Hashemi and H. Homayuni, "Emotional Divorce: Child's Well-Being," J. Divorce Remarriage, vol. 58, no. 8, pp. 631-644, 2017.

[8] K. Pantelis, K. Bonotis, and T. Kandri, "It Attacked My Change: An Exploratory Study with Young Adults on the Impact of Divorce and Their Adjustment Processes During Adolescence," J. Divorce Remarriage, vol. 56, no. 8, 2015.

[9] R. Crosse and M. Millar, "Irish Women's Ongoing Experiences of Domestic Abuse in Cases of Separation and Divorce," J. Divorce Remarriage, vol. 58, no. 7, 2017.

[10] A. Farida, Perempuan dalam Institusi Cerai Gugat di Tanggerang. Jakarta: Departemen Agama Republik Indonesia, 2007.

[11] W. F. Adilia and I. M. Said, "Ritual Posuo 'Pingitan' Pada Masyarakat Suku Buton: Kajian Semiotika," J. Ilmu Budaya, vol. 7, no. 2, 2019.

[12] M. Y. Harahap, Informasi Materi KHI. Mempositifkan Abstraksi Hukum Islam dalam KHI dan Peradilan Agama: dalam Sistem Hukum Nasional. Jakarta: Logos Wacana Ilmu, 1999.

[13] Departemen Pendidikan dan Kebudayaan, Kamus Wolio-Indonesia. Jakarta: Pusat Pembinaan dan Pengembangan Bahasa, 1985.

[14] M. M. Fahimuddin, Menafsir Ulang Sejarah dan Budaya Buton. Baubau: Respect, 2011.

[15] I. Engku, Masalah Posuo Bagi Gadis-Gadis Remaja sebagai Alat Pendidikan di Kabupaten Dati II Buton. Ujung Pandang: IAIN Alauddin, 1982.

[16] L. Fariki, Mengapa Perempuan Buton dan Muna Dipingit? Kendari: Komunika, 2009.

[17] Koentjaraningrat, Pokok-pokok Antropologi Sosial. Jakarta: Dian Rakyat, 1985.

[18] F. Alamsyah, "Onina Manga Mancuana Mangege: Ungkapan Tradisional Orang Wolio," Program Pascasarjana Universitas Gadjah Mada, 2018. 